\title{
AN EXPERIMENTAL STUDY EVALUATING THE INFLUENCE OF QUERCETIN ON MONOSODIUM GLUTAMATE-INDUCED DEPRESSION IN SWISS ALBINO MALE MICE
}

\author{
SRIRAM BS ${ }^{1}$, RAVICHANDRA V ${ }^{2 *}$ \\ Department of Pharmacology, K.S Hegde Medical Academy, Mangaluru -575 008, Karnataka India. \\ Email: ravi75chandra@yahoo.co.in
}

Received: 09 March 2019, Revised and Accepted: 10 April 2019

\section{ABSTRACT}

Objective: The objective of the study was to evaluate the antidepressant activity of quercetin in monosodium glutamate (MSG) model of depressed male mice.

Methods: MSG was administered (500 mg/kg) to different groups of albino male mice daily for 21 days to induce depression. The interventions (Quercetin and imipramine) were started on day $9^{\text {th }}$ and continued till $21^{\text {st }}$ day. On $23^{\text {rd }}$ day, mice are sacrificed, hippocampus and amygdala supernatant are subjected for analysis. $\mathrm{p}<0.05$ was considered as statistically significant.

Results: There was a statistically significant reduction in interleukin (IL)-6 levels in animals treated with quercetin and imipramine compared to control group $(\mathrm{p}<0.001)$. There was also a statistically significant increase in brain-derived neurotrophic factor (BDNF) levels in quercetin with MSG groups $(\mathrm{p}<0.05)$ and imipramine with MSG groups $(\mathrm{p}<0.01)$. There was no statistically significant difference in IL- 6 and BDNF levels between the groups of animals treated with quercetin $(100 \mathrm{mg} / \mathrm{kg})$ and imipramine $(10 \mathrm{mg} / \mathrm{kg})$ alone.

Conclusion: Quercetin appeared to have an antidepressant activity. More extensive research is required to substantiate and elucidate the role of quercetin in behavioral disorders such as depression.

Keywords: Monosodium glutamate, Quercetin, Imipramine, Interleukin-6, Brain-derived neurotrophic factor.

(C) 2019 The Authors. Published by Innovare Academic Sciences Pvt Ltd. This is an open access article under the CC BY license (http://creativecommons. org/licenses/by/4. 0/) DOI: http://dx.doi.org/10.22159/ajpcr.2019.v12i5.32986

\section{INTRODUCTION}

Depression is a heterogenous mood disorder affecting person behavior, physical, and mental health. The prevalence of major depression is found to be $20-25 \%$ in women and $7-12 \%$ in men [1]. The presence of comorbid conditions such as myocardial infarction, cancer, and diabetes mellitus increases the risk of depression [2-4]. Early diagnosis and management of depression help in improving quality of life and preventing suicide; it has been found that suicide rates are 2 times more in depressed individuals than that in general population [5].

Monosodium glutamate (MSG) is commonly known as Aji-nomoto and it is widely used as food additive to enhance flavour and taste in processed foods. Despite its popular use, there are reports which indicate MSG is toxic to humans and laboratory animals at high doses [6]. MSG can overexcite neuronal cells to the point of damage or death, resulting in the release of inflammatory mediators, and increase in oxidative stress. In a study, it has been found that MSG at a dose of $500 \mathrm{mg} / \mathrm{kg}$ body weight intraperitoneally causes a depression such as effect and serves as experimental models to induce depression in mice [7]

Quercetin (3,3,4,5,7-pentahydroxyflavone) is a flavonoid found in fruits and vegetables such as apples, onions, and berries [8-9]. Quercetin is present as glycosides in foods and is deglycosylated to quercetin aglycone before passive absorption in the small intestine [10]. The halflife of quercetin ranges between 11 and $28 \mathrm{~h}$ suggesting a correlation with plasma concentration on constant supplementation [11]. Quercetin is found to possess antioxidant, anticancer, neuroprotection, sirtuin gene modulating activity, and also as a phytoestrogen, mimicking natural estrogen hormone [12]. Hence, quercetin may work as a natural antidepressant; wherein current scenario lot of synthesized molecules are producing adverse effects.
In the current study, we evaluated antidepressant effects of quercetin on MSG-induced depression in male mice by estimating brain-derived neurotrophic factor (BDNF) and interleukin (IL)-6 levels in amygdala and hippocampus.

\section{METHODS}

MSG and quercetin were procured from Sisco Laboratories Pvt. Ltd., India. IL- 6 and BDNF enzyme-linked immunosorbent assay (ELISA) kits were purchased from Sigma-Aldrich Pvt., Ltd., India. Standard imipramine tablets (Tofranil) from Novartis Laboratory Pvt., Ltd., India, all other materials were of analytical grade. Male mice of 3 months old (25-30 g) were used for study, after obtaining permission from Institutional Animal Ethics Committee (115/1999) K.S. Hegde Medical Academy. They were kept in a standard laboratory environment with laboratory food and water ad libitum. $\mathrm{p}<0.05$ was considered as statistically significant.

The animals were grouped and administered drugs as follows ( $\mathrm{n}=6$ each).

Group 1 (Control): Normal saline $(1 \mathrm{ml})$

Group 2 (Positive control): MSG ( $500 \mathrm{mg} / \mathrm{kg}$ ) orally for 21 days

Group 3 (Test drug): Quercetin $(100 \mathrm{mg} / \mathrm{kg})$ started on the $9^{\text {th }}$ day and continued till $21^{\text {st }}$ day

Group 4 (Standard): Imipramine $(15 \mathrm{mg} / \mathrm{kg})$ started on the $9^{\text {th }}$ day and continued till $21^{\text {st }}$ day

Group 5: Positive control + Quercetin started on the $9^{\text {th }}$ day and continued till $21^{\text {st }}$ day

Group 6: Positive control +Imipramine started on the $9^{\text {th }}$ day and continued till $21^{\text {st }}$ day

The test and standard drugs were administered orally after diluting in $1 \mathrm{ml}$ of normal saline. The recommended dose of imipramine in a 
human was used to calculate the dose for experimental animal [13]. The selection dose of quercetin used was based on a previous study [14].

\section{IL-6 Estimation}

For ELISA, the hippocampal tissue was homogenized in $1 \mathrm{ml}$ buffer per $1 \mathrm{mg}$ tissue wet weight. The standard manufacturer's protocol was modified to optimize for the detection of cytokines in the brain tissue by the addition of fresh protease inhibitors to thawing homogenates and increasing the sample aliquot to $50 \mathrm{ml}$ (in duplicate) as well as extending the sample incubation time from $2 \mathrm{~h}$ to $4 \mathrm{~h}$. All samples were normalized for total protein. A standard curve was generated for IL-6 based on the standards provided [15].

\section{BDNF estimation}

BDNF levels in the amygdala were determined by sandwich-ELISA using monoclonal antibodies specific for BDNF. Total protein was measured by Bradford's method using bovine serum albumin as standard [16].

\section{Statistical analysis}

Statistical analysis was performed using GraphPad prism version 5.0. One-way Analysis of variance was performed followed by Tukey's test as post hoc. $\mathrm{p}<0.05$ was considered as statistically significant.

\section{RESULTS}

\section{Amygdala BDNF levels}

The amygdala BDNF levels were significantly reduced in positive control (MSG) group when compared to control (Fig. 1). The intervention groups treated with MSG, both standard and test drug showed a significant increase in BDNF levels and there are no significant changes in imipramine and quercetin alone treated groups.

\section{Hippocampal IL-6 levels}

The hippocampal IL-6 levels were significantly increased in the positive control group (MSG) indicating neuroinflammation (Fig. 2). The intervention groups treated with MSG, both standard and test drug showed a significant decrease in IL-6 levels and there are no significant changes in imipramine and quercetin alone treated groups.

\section{DISCUSSION}

Depression is widely associated with other disorders such as obesity, hypothyroidism, diabetes mellitus, and also cancer. Depressed people are twice likely prone to committing suicide compared to the normal population [17]; hence, management of depression without adverse effects is essential to prevent morbidity and mortality associated with it.

In the present study, antidepressant effects of quercetin on MSG-induced depression were evaluated using the estimation of IL-6 and BDNF levels by ELISA in hippocampus and amygdala of male mice brain. Since majority antidepressants alter BDNF levels and also changes in BDNF levels takes place exactly after 1 week of antidepressant therapy which helps in understanding the therapeutic potential of antidepressants which takes weeks together to observe clinical benefits, thus BDNF estimation helps in understanding antidepressant actions of the test drug [18].

Recent evidence indicates the role of IL- 6 as an inflammatory marker in depression; therefore, drugs which decreases IL-6 levels helps in the management of depression [19].

In study quercetin antagonized cognitive impairment induced by feeding mice with high-fat diet [20]. Quercetin activates the Nrf2-ARE pathway which provides neuroprotection against oxidative damage and cell death. More recent evidence suggests that the Nrf2-ARE pathway may modulate the formation and degradation of misfolded protein aggregates which are present in various neurodegenerative diseases (Parkinson's, Alzheimer's, and Huntington's diseases) and amyotrophic lateral sclerosis [21].

In addition, quercetin also inhibits cytokine production by astrocytes. The cellular/molecular mechanisms for the anti-inflammatory effects

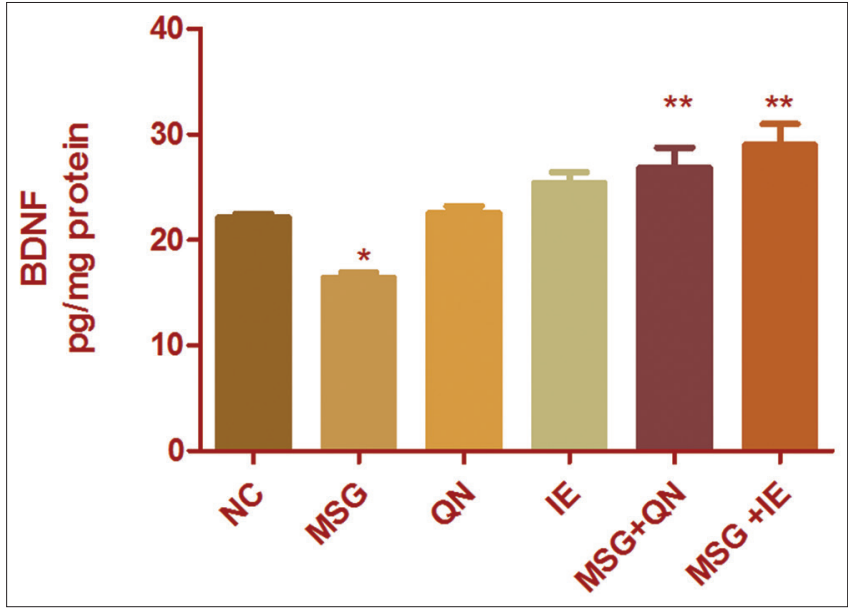

Fig. 1: Effect of various treatments on amygdala brain-derived neurotrophic factor levels ${ }^{*} \mathbf{p}<0.05$ compared to control; ${ }^{* *} \mathbf{p}<0.001$ compared to positive control); $\mathbf{n}=6$ in each group; data are represented as mean \pm S.D

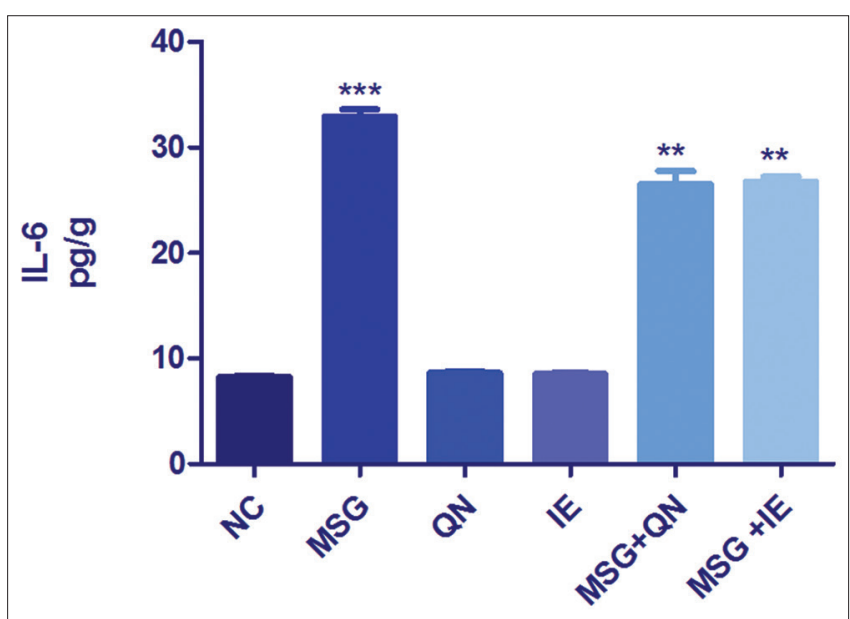

Fig. 2: Effect of various treatments on hippocampus IL-6 levels $\left({ }^{* * *} \mathbf{p}<0.0001\right.$ compared to control; ${ }^{* *} \mathbf{p}<0.05$ compared to positive control); $n=6$ in each group; data are represented as mean $\pm S . D$

of quercetin are not known, but a possible pathway may be related to the induction of PON2 [22] which has anti-inflammatory activity in addition to its antioxidant activity which may explain its role in decreasing inflammatory mediators involved in depression and exhibiting possible antidepressant effects.

At present, quercetin is considered to be a nutritional supplement and further research to improve its bioavailability and distribution in cerebrospinal fluid and its role in the treatment of neurological disorders has to be established.

\section{CONCLUSION}

Flavonoid quercetin has shown a significant increase in BDNF and decreases in IL-6 levels as compared to the standard antidepressant drug imipramine. However, further studies including the evaluation of its effect on the biochemical, molecular, and cellular pathway are required to establish its role as an antidepressant drug.

\section{ACKNOWLEDGMENT}

We would like to thank Dr. Rajendra Holla, Professor and HOD Department of pharmacology for extending support and encouragement for the study. 


\section{AUTHORS' CONTRIBUTION}

The first author (S.B.S) initiated and conducted the research. The second author (R.V) conducted animal care and prepared the manuscript.

\section{CONFLICTS OF INTEREST}

The author(s) declare(s) that they have no conflicts of interest to disclose.

\section{REFERENCES}

1. Rihmer Z, Angst J. Mood disorders: Epidemiology. In: Sadock BJ, Sadock VA, editors. Kaplan and Sadock's Comprehensive Textbook of Psychiatry. $8^{\text {th }}$ ed. Philadelphia, PA: Lippincott, Williams and Wilkins; 2005. p. 1576-82.

2. Mayou RA, Gill D, Thompson DR, Day A, Hicks N, Volmink J, et al. Depression and anxiety as predictors of outcome after myocardial infarction. Psychosom Med 2000;62:212-9.

3. Bottomley A. Depression in cancer patients: A literature review. Eur J Cancer Care (Engl) 1998;7:181-91.

4. Aithal S, Hooli TV, Patil R, Varun HV, Swetha ES. Evaluation of antidepressant activity of topiramate in mice. Asian J Pharm Clin Res 2014;7:174-6.

5. Torgal SS, Amitha N. An experimental study evaluating the influence of bisphosphonates on depression patterns in swiss albino mice and Wister rats. Int J Pharm Pharm Sci 2017;9:187-91.

6. Umukoro S, Oluwole GO, Olamijowon HE, Omogbiya AI, Eduviere AT. Effect of Monosodium glutamate on behavioral phenotypes, biomarkers of oxidative stress in brain tissues and liver enzymes in mice. World $\mathbf{J}$ Neurosci 2015;5:339-49.

7. Abrahamse SL, Kloots WJ, van Amelsvoort JM. Absorption, distribution, and secretion of epicatechin and quercetin in the rat. Nutr Res 2005;25:305-17.

8. Kawabata K, Mukai R, Ishisaka A. Quercetin and related polyphenols: New insights and implications for their bioactivity and bioavailability. Food Funct 2015;6:1399-417.

9. Guo Y, Bruno RS. Endogenous and exogenous mediators of quercetin bioavailability. J Nutr Biochem 2015;26:201-10.

10. Manach C, Williamson G, Morand C, Scalbert A, Rémésy C. Bioavailability and bioefficacy of polyphenols in humans. I. Review of 97 bioavailability studies. Am J Clin Nutr 2005;81:230S-242S.

11. de Boer VC, Dihal AA, van der Woude H, Arts IC, Wolffram S,
Alink GM, et al. Tissue distribution of quercetin in rats and pigs. J Nutr 2005; $135: 1718-25$

12. Ruotolo R, Calani L, Brighenti F, Crozier A, Ottonello S, Del Rio D, et al. Glucuronidation does not suppress the estrogenic activity of quercetin in yeast and human breast cancer cell model systems. Arch Biochem Biophys 2014;559:62-7.

13. Molinoff PB. Neurotransmission and central nervous system. In: Brunton LL, Chabner BA, Knollmann BC, editors. Goodman and Gilman's the Pharmacological Basis of Therapeutics. $12^{\text {th }}$ ed. New York: McGraw Hill; 2011. p. 364-81.

14. Ghosh MN. Fundamentals of Experimental Pharmacology. $5^{\text {th }}$ ed. Kolkota: Hilton and Company; 2011. p. 165-72.

15. Maes M, Bosmans E, De Jongh R, Kenis G, Vandoolaeghe E, Neels H, et al. Increased serum IL-6 and IL-1 receptor antagonist concentrations in major depression and treatment resistant depression. Cytokine 1997;9:853-8.

16. Garcia LS, Comim CM, Valvassori SS, Réus GZ, Barbosa LM, Andreazza AC, et al. Acute administration of ketamine induces antidepressant-like effects in the forced swimming test and increases BDNF levels in the rat hippocampus. Prog Neuropsychopharmacol Biol Psychiatry 2008;32:140-4

17. Sidney H. Kennedy, Rizvi SJ. Comparative efficacy of newer antidepressants for major depression: A Canadian perspective. Can J Diagn 2009;20:81-6.

18. Tanwani H, Nyati P, Atal S, Churihar R. Evaluation of antianxiety, antidepressant and sedative effects of nimodipine in Swiss albino mice. Int J Pharm Pharm Sci 2016;8:260-3

19. Zhou H, Zhang H, Cui J, Liu Y, Wu R, Xiang H. Protoponaxidiol saponins in the caudexes and leaves of Panax notoginseng could be the main constituents for its antidepressant effects. Int J Pharm Pharm Sci 2014;6:301-1

20. Xia SF, Xie ZX, Qiao Y, Li LR, Cheng XR, Tang X, et al. Differential effects of quercetin on hippocampus-dependent learning and memory in mice fed with different diets related with oxidative stress. Physiol Behav 2015;138:325-31.

21. Arredondo F, Echeverry C, Abin-Carriquiry JA, Blasina F, Antúnez K, Jones DP, et al. After cellular internalization, quercetin causes nrf2 nuclear translocation, increases glutathione levels, and prevents neuronal death against an oxidative insult. Free Radic Biol Med 2010;49:738-47.

22. Bureau G, Longpré F, Martinoli MG. Resveratrol and quercetin, two natural polyphenols, reduce apoptotic neuronal cell death induced by neuroinflammation. J Neurosci Res 2008;86:403-10. 